\title{
COMMENTS
}

\section{JUDICIAL REVIEW AND THE UNCERTAIN APPEAL OF CERTAINTY ON APPEAL}

\author{
RONALD M. LEVIN†
}

In their Article Judicial Incentives and Indeterminacy in Substantive Review of Administrative Decisions, ${ }^{1}$ Sidney A. Shapiro and Richard E. Levy have raised in an intriguing way soine panoramic questions about the role of judicial review in administrative law. They offer both an ambitious theory of judicial behavior and a proposed rewrite of section 706 of the Adininistrative Procedure Act (APA), ${ }^{2}$ the scope of review section.

Tying these themes together is the authors' effort to understand how the legal system can promote "determinacy" in judicial review of agency actions. They argue that norms of "craft" (i.e., doctrinal rules) are always in tension with judges' desires to promote their preferred substantive outcomes, but that courts are particularly inchined to pursue the latter at the expense of the former in administrative law. Because, in their view, courts are incapable of establishing any consistent analytical frainework for resolving administrative law cases, Shapiro and Levy turn to Congress as the best hope for instilling order in judicial review doctrine.

Despite my appreciation of their endeavor, however, I neither favor the specific statute they offer ${ }^{3}$ nor believe that Congress should be asked to consider any revision of section 706 . The merit of Shapiro and Levy's analysis, at least for me, is that it highlights some lingering problems in scope of review doctrine and, just as importantly, raises worthwhile questions about how much we really want doctrine to control the outcome of appeals from administrative decisions.

First, I examine the issue of how much clarity and predictability we can fairly expect from scope of review doctrine. While this entails scrutimy of Shapiro and Levy's imteresting model of judicial

$\dagger$ Professor of Law, Washington University.

1. 44 DUKE L.J. 1049 (1995).

2. 5 U.S.C. $\& 706$ (1988).

3. Shapiro \& Levy, supra note 1 , at 1071-72. 
behavior, the points that I raise will be more normative than descriptive in character. My doubts that "determinacy" is as desirable as Shapiro and Levy assume also lead me to disagree with the authors' strategy of looking to Congress to improve the clarity of scope of review doctrine. In Part II, I look more concretely at Shapiro and Levy's proposed statute and highlight some difficulties in draftimg a comprehensive statute. I conclude with some remarks about the potential role of scliolarship in amelioratimg the uncertainties of scope of review doctrine.

\section{THE QUEST FOR DETERMINACY}

\section{A. The Shapiro-Levy Model of Judicial Behavior}

Sliapiro and Levy seem frustrated that the Supreme Court's opmions in Chevron, U.S.A., Inc. v. Natural Resources Defense Council, Inc. ${ }^{4}$ and Motor Vehicle Manufacturers Ass'n v. State Farm Mutual Automobile Insurance Co. ${ }^{5}$ have never dommated judicial review as they were "supposed" to. ${ }^{6}$ Their disappointment that this has not occurred leads them to undertake an extended exploration, using social choice theory, of the reasons why judges do not always toe the lines that doctrine seems to dictate and why courts often shy away from announcing restrictive "lines" in the first place, especially in administrative law settings. The authors posit three factors that motivate judges: "craft," which is defined as "tlie well-reasoned application of doctrine"; "outcome," which is "tlie result sought in the mdividual case"; and "leisure," which roughly means the opportunity to go fishing instead of spending a lot of time worrying about opimion-writing." The authors' "basic contention is that a judge's outcome orientation is a function of the determinacy of craft norms." Tlius, when rules of law are phrased in a manner that gives definite direction to the courts, judges are less likely to render result-oriented rulings because flagrant floutmg of "craft" norms threatens thein with reversal, damage to their reputations, and other consequences that judges tend to dislike.
4. 467 U.S. 837 (1984).
5. 463 U.S. 29 (1983).
6. See Shapiro \& Levy, supra note 1, at 1049-50.
7. Id. at $1051-52$.
8. Id. at 1056. 
I will not dwell on the specifics of this descriptive model because the basic conclusion seems clearly correct. I will add only a few comments.

In the first place, I see no inherent reason to associate "craft" with administrative law and "outcome" with substantive law. For judges who are ideologically attracted to the norms of administrative law, craft and outcome motivations should converge; that is, if a judge has an ideological commitinent to "deference," she can adhere to her idea of "craft" and take satisfaction in the "outcome" at the saine time. ${ }^{9}$ Conversely, once a principle of substantive law has become established, a judicial devotee of "craft" will presumably feel compelled to honor it, even if she disagrees with it. It would seem, then, that "outcome orientation" should be understood as a desire to pursue a result that would be inconsistent with whatever result (or range of results) the applicable "craft" principles would permit, whether the latter principles are substantive or procedural. ${ }^{10}$ Shapiro and Levy can still argue, of course, that the pursuit of "outcome" tends to diminish as the specificity of craft norms increases; however, the multiplicity of craft norms raises some questions about their nornative analysis, as we shall see.

Second, there is the empirical question of the strength of the relationship that Shapiro and Levy posit. Law reviews have seen much debate about the extent to which doctrine constrains judges. ${ }^{11}$ As one who has spent much of an academic career writing

9. For an example of such commitment on the part of one jurist, see Laurence $\mathrm{H}$. Silberman, Chevron-The Intersection of Law \& Policy, 58 GEO. WASH. L. REV. 821, 821 (1990) ("Those of us who have decried the extraordinary expansion of judicial power in the latter half of this century might be thought to stand for a 'little judiciary' and ... we should bear the emblem proudly.").

10. Shapiro and Levy's distinction may be at its best in the context of agency adjudications. When a court reviews an agency's application of settled law to novel fact situations, it might well be meaningful to speak of the competing pulls of "craft" (the law) and "outcome" (exceptional equities of an individual case). But rulemaking proceedings, particularly ones that reach the Supreme Court, typically involve the reconciliation of competing policies rooted in the underlying substantive law. These policies may well embody craft norms that a court should bear in mind.

11. Compare, e.g., Harry T. Edwards, Public Misperceptions Concerning the "Politics" of Judging: Dispelling Some Myths About the D.C. Circuit, 56 U. CoLO. L. REv. 619, 620 (1985) ("[1]t is the law-and not the personal politics of individual judges-that controls judicial decision-making in most cases resolved by the Court of Appeals.") and Alvin B. Rubin, Doctrine in Decision-Making: Rationale or Rationalization, 1987 UTAH L. REV. 357,357 (1987) ("My conclusions are that legal doctrine is a real force, that judges fol- 
about scope of review principles, ${ }^{12}$ I prefer to believe that they liave at least some influence. Still, a simple sense of realism would suggest that the extent to which scope of review principles actually affect results is likely to depend in part on the kind of case involved. Illustrative of one end of the spectrum is Rust $v$. Sulli$v a n,{ }^{13}$ better known as the "gag rule" case. When the Court decided Rust, there was probably no one in America who failed to suspect that the Justices' (or at least some Justices') respective views on abortion had more to do witl their votes than did their attitudes towards deference.

On the other liand, many cases do not mvolve sucli high stakes and public passions. In those cases, it is much easier to beheve that judges are honestly willing to be guided by their understanding of scope of review principles. Occasionally, one observes a Justice stating that he is voting to uphold an agency's imterpretation but would have voted the other way had the agency's view been different. ${ }^{14}$ In cases like thIS, which typically are obscure cases im which a judge might have no strong convictions one way or the other, I should think only the diehard cynic or legal reakst would regard such statements as insincere. ${ }^{15}$

low legal rules in deciding cases ....") with, e.g., Girardeau A. Spann, Simple Justice, 73 GEO. LJ. 1041, 1081 (1985) ("[J]udicial decisions are constrained only by the subjective preferences of the judges who issue them.").

12. See, e.g., Ronald M. Levin, Understanding Unreviewability in Administrative Law, 74 MINN. L. REV. 689 (1990) [hereinafter Levin, Understanding Unreviewability]; Ronald M. Levin, Scope-of-Review Doctrine Restated: An Administrative Law Section Report, 38 ADMIN. L. REV. 239 (1986) [hereinafter Levin, Restatement Report]; Ronald M. Levin, Administrative Discretion, Judicial Reviev, and the Gloomy World of Judge Smith, 1986 DUKE L.J. 258; Ronald M. Levin, Identifying Questions of Law in Administrative Law, 74 GEO. L.J. 1 (1985) [hereinafter Levin, Identifying Questions].

13. 500 U.S. 173 (1991) (upholding, assertedly on the basis of Chevron, regulation forbidding abortion counseling at federally funded clinics).

14. See, e.g., Regents of Univ. of Cal. v. Public Employees' Relations Bd., 485 U.S. 589, 603-04 (1988) (White, J., concurring); Lukhard v. Reed, 481 U.S. 368, 383 (1987) (Blackmun, J., concurring) ("I would base my vote to reverse ... flatly, on the deference that is due the Secretary ....."); Pattern Makers' League v. NLRB, 473 U.S. 95, 117 (1985) (White, J., concurring).

15. Professor Schauer has similarly suggested that the Justices often use "plain meaning" analysis of statutory questions in order to dispose of relatively uninteresting cases without delving deeply into the underlying purposes of an enactment. Frederick Schauer, Statutory Construction and the Coordinating Function of Plain Meaning, 1990 SUP. CT. REV. 231, 253-55. Unlike the principles of interpretation discussed by Schauer, however, casual adherence to the principle of deference is not neutral between the parties involved; it systematically favors the government. The practical lesson, of course, is that private counsel have the de facto burden of making their case interesting and compelling 
Shapiro and Levy further argue that judges are especially prone to adopt indeterminate craft norms in cases involving administrative law. They cite two reasons for this tendency. First, important public policies are more often at stake in these cases. ${ }^{16}$ Second, judges know that power shifts back and forth between the niajor political parties over time; they are anibivalent about how tightly to tie agencies' hands because they do not know whether they will favor or oppose the causes that toniorrow's administrators will pursue. ${ }^{17}$

Both of these arguments are open to question. The idea that adınimistrative law cases present more than their share of exciting and passion-inspiring issues is not exactly self-evident. ${ }^{18}$ Like cases in other areas, regulatory cases are sometimes engaging and glamorous, at other times, narrow and mundane. In fact, Shapiro and Levy's argument seenis seriously weakened by their own concession that the "vast nuajority" of adıministrative law cases probably lack important public policy implications. ${ }^{19}$ Nor is admimistrative law litigation umique in regularly calling upon judges to enunciate rules of law that may help their ideological soulmates today but could easily hurt them tomorrow. Courts frequently encounter a similar "veil of ignorance" in kindred procedural fields such as civil procedure and remedies.

Despite these doubts, I agree with the general thrust of Shapiro and Levy's position that pronouncements such as those in

enough to overcome an initial disposition to uphold the government.

16. Shapiro \& Levy, supra note 1 , at 1061.

17. Id. at 1062 .

18. Cf. Thomas M. Susman, Now More Than Ever: Reauthorizing the Administrative Conference, Reforming Regulation, and Reinventing Government, 8 ADMIN. L.J. AM. U. 677,682 (1994) ("Administrative procedure, simply stated, is not sexy stuff. It seldom produces headline news or even spirited public debate. Administrative procedure is the stuff of speeclies that makes audiences doze."). I recall a workshop for administrative law professors soine years ago at which Professor Richard B. Stewart quipped that law school courses in administrative law should be accorded some sort of handicap in the annual student teaching evaluations. Most of the audience seemed to know what he meant.

19. Shapiro \& Levy, supra note 1 , at $1061 \mathrm{n} .39$. It is no answer to say, as Shapiro and Levy do, that there are important public policy considerations in a "significant portion of high-profile cases, particularly those that make it to the Supreme Court." Id. The issue is whether this holds true more often in administrative law than in other types of law; I am skeptical about this point. Obviously, only the most important cases make it to the Supreme Court, no matter what the field of law. Moreover, although the Supreme Court receives only the tastiest morsels from the administrative law menu, that fare probably seems bland when compared with the rich diet of constitutional law cases on which the Court regularly feeds. 
Chevron and State Farm are particularly susceptible to indeterminacy. I would explain this tendency on the basis of factors that relate to scope of review primciples in particular, not to admmistrative law in general.

First, the great majority of cases in which a court might address scope of review arise in a context in which the judges are focusing primarily on the substantive issues in the case. Those substantive issues will probably be the principal point in dispute (or, in a Supreme Court case, the reason the Court granted review). Thus, scope of review often enters the picture as an incidental inatter-one that the parties have scarcely addressed, if at all. These circumstances alone inay help explain why language $\mathrm{m}$ judicial opinions purporting to state a standard of review is often written without the kimd of attention for which a purist might hope.

Second, the incentives that normally induce the Court to write its opinions carefully may be lower in scope of review contexts than in others, because the Court decides some two dozen administrative cases every term. If today's draft opinion contains loose language on standards of review, the Justices know they will have a chance soon to counteract it. This inevitable multiplicity of pronouncements removes some of the pressure on any given opinion writer to worry about nuance, to reconcile seeming conflicts in past dicta, and to expound scope of review principles in a comprehensive inanner. Conversely, the Court has stronger incentives to be precise in most substantive regulatory areas, because the guidance presented in a single opinion may be all that the Court will say on that particular subject for years to come. In short, the Court's writing about scope of review can be seen as illustrating a relationship that any economic nodeler would find easy to understand: talk is cheap when the supply of it is plentiful.

One can easily extend this last point to take into account the relationships among the Justices. In opinion-writing generally, the Justices tend to act as advocates, using their rhetorical skills to make the strongest possible case for their side, often not shrinking from a bit of hyperbole in the process. Tendencies toward exaggeration are usually linited by the author's need to negotiate with colleagues over the terms of the opinion. Where scope of review language is concerned, however, the incentive for fellow Justices to object to overstatements is relatively low, because, as just explained, each of thein knows that any thetorical excess will proba- 
bly be offset by countervailing rhetoric before the term ends. In this context, it is not surprising that members of the Court stress the importance of deference im cases in which they happen to be upholding the agency's view. It is also not surprising that they stress the importance of judicial checks on bureaucratic oppression when they have decided to reject the agency's view. Who would expect otherwise? ${ }^{20}$

\section{B. Determinacy: Who Needs It?}

Shapiro and Levy see a need to "reform" judicial review doctrine in order to make craft norms as determmate as possible, thereby minimizing the influence of "outcome orientation." Nowhere, however, do they defend the desirability of their objective. Determinacy is obviously somewhat desirable, but to what extent? At what price? I will attempt to explore these questions here.

At the outset, it is helpful to recognize an ambiguity regarding the extent to which Shapiro and Levy are seeking determinacy as opposed to deference. Portions of their argument carry at least an implication that, in their view, courts are in general too intrusive in their scrutiny of admimistrative actions. Their abiding dismay at "outcome orientation" and their failure to condemn any judicial decision for being too deferential reinforce the impression that one of their principal concerns is "overly aggressive judicial review."21 Yet they do not make a sustained case for increased deference, and indeed one would expect some hesitation on this score from authors who have previously been, and apparently remain, advocates of "heiglitened scrutiny of the fourth branch" through a vigorous application of State Farm. ${ }^{22}$ They rest their

20. Similar reasoning may help to explain why statutory interpretation doctrine has historically displayed the same kind of inconsistencies and vagueness that characterize scope of review doctrine. This is another realm in which a plentiful supply of talk cheapens the value of any particular pronouncement.

To be sure, Justices Scaha and Thomas have recently departed from the usual mold by refusing on principle to join any opinion that relies significantly on legislative history. The very fact that this is unusual-most Justices do not attach such importance to method-gives these two Justices unusual bargaining power on this particular issue, although presumably less on others. See Thomas W. Merrill, Textualism and the Future of the Chevron Doctrine, 72 WASH. U. L.Q. 351, 365-66 (1994). Deference, however, is apparently a matter that most are willing to bargaim about; it is a circumstance that facilitates consensus but militates against clarity.

21. Shapiro \& Levy, supra note 1 , at $\mathbf{1 0 7 0 .}$

22. See Sidney A. Shapiro \& Richard E. Levy, Heightened Scrutiny of the Fourth 
program of reform primarily on a more abstract appeal to the virtues of clarity and consistency, and I will respond to them on that level.

One gathers that the authors' basic reason for pursuing determinacy is a concern for legitimacy in the judicial review process. Determinate standards of review, they suggest, deter judges from deciding cases on the basis of personal value judgments and from applying divergent modes of analysis to similar cases. ${ }^{23}$ Thus, such standards serve the rule of law. At a minimum, judicial review standards can put pressure on courts to defend their (imevitably value-influenced) positions on acceptable grounds. And perhaps, once in a while, they do alter outcomes, and do so in a manner that Shapiro and Levy's behavioral model aptly describes: a judge might conclude that, given the applicable standard of review, reversal of an agency would simply not be credible (or not be credible enough to warrant the injury to his reputation and self-image that would result from such "activism"). ${ }^{24}$

Up to a point, this rationale for consistent, easy-to-apply judicial review doctrines is obviously quite appeahing. Additionally, one could note the practical value of such doctrimes for agencies and meinbers of the public, who benefit when they can plan their primary conduct with some ability to predict what would happen if a controversy were to end up in court.

The administrative law system has not, however, always assumed that latitude for judicial creativity is altogether bad. Recall the traditional perspective refiected in one of the greatest of the Supreme Court's scope of review opinions, Universal Camera Corp. v. NLRB: ${ }^{25}$

A formula for judicial review of administrative action may afford grounds for certitude but cannot assure certainty of application. Some scope for judicial discretion in applying the formula can be avoided only by falsifying the actual process of judging or by using the formula as an instrument of futile casuistry. It cannot be too often repeated that judges are not automata. ${ }^{26}$

Branch: Separation of Powers and the Requirement of Adequate Reasons for Agency Decisions, 1987 DUKE L.J. 387, 425.

23. Shapiro \& Levy, supra note 1 , at 1056.

24. See id. at 1058 .

25. 340 U.S. 474 (1951).

26. Id. at $488-89$. 
Any suggestion that courts may properly keep an "outcome" orientation in mind may seein to invite too lawless a role for the judiciary, which should instead mamtain its allegiance to "craft" according to Shapiro and Levy's worldview. As I discussed earlier, however, it is fallacious to align administrative law values exclusively on the "craft" side of the divide and substantive concerns entirely on the "outcome" side. ${ }^{27}$ Judges, particularly at the Supreme Court level, often feel a responsibility to try to bring coherence to the specific area of substantive law involved in a given case. ${ }^{28}$ When a court strains the outer limits of the applicable standards of review in order to pursue this objective, we teachers of admimistrative law may condenin the court's decision as unprincipled, but our colleagues down the hall who teach environmental law, securities law, or labor law may praise the opinion as an exemplary work of "craftsmanship."29

Furthermore, substantive judicial review is an inherently subtle and complex subject. Often the situations that a proposed scope principle must cover include highly formalized adninistrative settings such as formal adjudications, high-stakes rulemaking pro-

27. See supra notes 9-10 and accompanying text.

28. See, e.g., Lechmere, Inc. v. NLRB, 502 U.S. 527 (1992) (rejecting agency interpretation that the court found to be inconsistent with settled substantive law); Maislin Indus., U.S. v. Primary Steel, Inc. 497 U.S. 116 (1990) (same). Though probably stated too strongly for modern sensibilities, Professor Jaffe's eloquent words remain perhaps the best expression of this impulse:

An agency is not an island entire of itself. It is one of the many rooms in the inagnificent inansion of the law. The very subordination of the agency to judicial jurisdiction is intended to proclain the premise that each agency is to be brought into harmony with the totality of the law; the law as it is found in the statute at hand, the statute book at large, the principles and conceptions of the

"common law," and the ultimate guarantees associated with the Constitution.

LOUIS L. JAFFe, JUdiCIAL CONTROL OF ADMINISTRATIVE ACTION 590 (1965).

29. For example, the authors breezily dismiss NLRB v. Bell Aerospace Co., 416 U.S. 267 (1974), as a case in which the Court "did precisely what it reversed the circuit court for doing in Hearst," i.e., manipulating standards of review in order to pursue a favored outcome. Shapiro \& Levy, supra note 1, at 22 n.67 (quoting RICHARD J. PIERCE, JR. ET AL., AdMINistrative LAW AND PROCESS $\& 7.4$, at 349 (2d ed. 1992)). Yet the Court found in Bell Aerospace that "the Board's early decisions, the purpose and legislative history of the Taft-Hartley Act of 1947, the Board's subsequent and consistent construction of the Act for more than two decades, and the decisions of the courts of appeals" demonstrated that the Board had misread the Act in the decision under review. 416 U.S. at 289. Read at face value, this assertion would tend to indicate that Bell Aerospace was a sterling example of the Court's devotion to "craft." I do not know whether the Court's account of substantive law in this five-to-four ruling was accurate, but neither do I see how anyone else could fairly assess the Court's "craftsmanship" except by making a close study of the applicable legislation, precedents, and policies in labor law. 
ceedings, highly informal actions such as letters and press releases, and mass-justice programs in which an agency has to move cases quickly in order to stay on top of its workload. One can easily imagine a court feeling daunted at the prospect of saying anything that is supposed to be reliable in all of these situations.

Despite the structural obstacles analyzed in the preceding section, I assuine the Court frequently can, when it chooses, prescribe a restrictive legal standard and make it stick. ${ }^{30}$ The equivocation we see on scope of review inay stem in part from inherent tensions that the Justices think cannot easily be alleviated. Ideologues at either end of the spectrum may subscribe to a "consistent" view of deference, but jurists in the middle are likely to take a less inflexible view. Perhaps their reluctance to try to settle the law too quickly stems from proper judicial caution, including an intuition that deference really ought to depend on context, i.e., that "it all depends."

In seeking the most promising opportunities for improvement in the law on substantive judicial review, I would distinguish more sharply than Shapiro and Levy do between two of the objectives they espouse: curbing open-ended standards and curbing inconsistencies in the courts' choices of standards. ${ }^{31}$ The latter involve what Shapiro and Levy call categorization problems-disagreements over what framework to use in a given case. ${ }^{32}$

Attempts to curtail vague categories, so as to bring about "determinacy" of results, is subject to Justice Frankfurter's cautionary words in Universal Camera. Efforts to prescribe a widely acceptable framework for analysis that should be invoked in a given context inay often be more fruitful. Although the record of recent years may not be as encouraging as one might desire, one can plausibly hope that, with the aid of scholars like Sliapiro and Levy, ${ }^{33}$ the courts will eventually reach a greater degree of con-

30. I have previously contrasted the Court's treatment of Vermont Yankee Nuclear Power Corp. v. Natural Resources Defense Council, Inc., 435 U.S. 519 (1978), and Heckler v. Chaney, 470 U.S. 821 (1985), in this regard. In Vermont Yankee, the Court made very clear its intention to curb judicial imposition of nonstatutory procedural requirements in rulemaking, and lower courts have generally respected its stern admonition. In Chaney, the Court showed less resolve in discouraging judicial review of enforcement discretion, and lower courts have thus felt bolder about limiting the scope of the Court's holding. See Levin, Understanding Unreviewability, supra note 12, at 778.

31. See Shapiro \& Levy, supra note 1 , at $\mathbf{1 0 7 0 .}$

32. Id.

33. See Levin, Identifying Questions, supra note 12, at 14-16, $62-63$ (advocating schol- 
sensus on what questions to ask under certain circumstances during substantive judicial review. This development would serve to reduce the influence of what Shapiro and Levy call "manipulable categories." 34

Yet even here I would offer a caveat. Whether to maintain a particular set of categories should depend heavily on whether the distinction underlying them is valid: Does the agency deserve deference inore in one case than in the other? An affirmative answer constitutes a strong argument for preserving the distinction, even though judges may have rooin to maneuver if the application of the distinction is not self-evident. Sometimes our main concern is that the law be "settled"; at other times we prefer that it be "settled right." Therefore, at least until we have had enough experience with a given standard of review to say that it has proved its worth in the precise form in which it is couched, courts should at least be open to considering whether refinements and exceptions to it are warranted. ${ }^{35}$

\section{Can Congress Do It Better?}

So pessimistic are Shapiro and Levy about the chances that the courts could straighten out the inconsistencies and vagueness of scope of review doctrine that they wind up proposing legislative action. Congress, they believe, should step in and impose standards of review that would effectively prevent judges from imposing their own value preferences on administrative action. Here I fear the authors' commitment to "determinacy" has led them to endorse a plan that could have far worse consequences than the situation it seeks to cure.

arship to clarify standards of review).

34. The goals of curtailing vague standards and of avoiding categorization problems are sometimes in tension. The very open-endedness of certain standards of review may be part of what enables judges to agree to use them. For example, the meaning of "substantial evidence" has been fairly stable and satisfactory for several decades, as has the meaning of the "clearly erroneous" test of Federal Rule of Civil Procedure 52(a). No doubt part of the reason for the stability of these tests is that they are plirased at a high level of generality that affords judges some room for ad loc judgment.

35. To be sure, if our legal system is going to tolerate the Court's giving itself some room to maneuver, other participants in the process, specifically lower courts and counsel, must avoid taking the Court's pronouncements too seriously. That may be a difficult message to offer to judges who properly recognize their duty to respect the teachings of higher courts. Thoughtful judges recognize, however, that the Supreme Court speaks with varying levels of seriousness and consistency on different occasions. 
To imagine that Congress would take action anytime soon to adopt the statute that Shapiro and Levy propose, one would have to be able to envision Senator Robert Dole and Speaker Newt Gingrich joining forces to support legislation that would protect agencies run mostly by President Clinton's appointees froin interference by judges appointed by Mr. Clinton's two Republican predecessors. It is not exactly a surprise that the Contract Witl America contained no provision of this kind.

Undoubtedly, Sliapiro and Levy would reply to this flippant put-down by saying that their proposal is only a preliminary suggestion that addresses the indefinite future, not the immediate present. I liave, however, a serious reason for injecting a note of realpolitik into the discussion. My real point is that if one's goal is to promote colierence and an apolitical attitude in the judicial review system, the congressional arena is an exceedingly poor venue in whicls to seek a solution. The irony is that Shapiro and Levy have constructed their article on the foundations of a "social clioice" theoretical inodel that, for analytical purposes, treats judges as political strategizers. This style of analysis can soinetimes yield useful insights, but those who would look to Congress to overcome the problems that such analysis uncovers should also be wary of what real politicians uniglit do with the same set of issues. $^{36}$

Shapiro and Levy have either forgotten or chosen not to draw lessons from the last time Congress took an active interest in specifying the scope of judicial review of adıninistrative action. The imitiative was known as the Bumpers Amendinent after its chief sponsor, Senator Dale Bumpers of Arkansas, and was in vogue in the late 1970s and early 1980s. The Bumpers Amendment would have added language to section 706 providing that "there shall be no presuinption that any rule or regulation of any agency is valid." ${ }^{37}$ Indeed, the burden would have been on the agency to es-

36. Some of the early work by social choice theorists (sometimes called positive pohitical theorists) has treated judges as neutral, Olympian figures that can play a useful role counteracting the self-interested tendencies of the legislative branch. This perspective can be criticized for not taking into account the fact that judges, too, have political agendas. See Daniel B. Rodriguez, The Positive Political Dimensions of Regulatory Reform, 72 WASH. U. L.Q. 1, 33-34, 91 (1994) (noting the limitations of this perspective). It seems considerably more curious to conceive of Congress, which by constitutional design is the branch that is closest to the people, as an appropriate entity to rein in judges who might behave in an overly political fashion.

37. 125 CONG. REC. 23,478 (1979). 
tablish the vahdity of a challenged rule "by a preponderance of the evidence shown."38

That was a period in whicl the mood of the country was deeply skeptical about government and in which there was broad support in Congress for reducing the scope and influence of the federal establishment. In short, it was quite similar to the doimnant spirit in Congress today. No wonder, then, that in the fall of 1979, whien Senator Bumpers brouglit up his proposal as a floor amendment to an unrelated bill, witlout any committee action, the Senate passed it by a vote of $51-27 .^{39}$

Some might think it unfair to take the Senate's impulsive gesture as a measure of what Congress would do with judicial review reform. After all, part of the Constitution's plan is that the numerous hurdles of the bicameral legislative process are supposed to induce deliberation and improvement of proposals that may be crude or extreme at the outset. Indeed, as the "regulatory reform" inovement lurclied forward over the next three years, the amendment went througli numerous revisions as part of the various reform bills. ${ }^{40}$ Let us, therefore, flasl forward to 1982 and look at the Bumpers Amendment in its most sophisticated and refined form-the version that was almost enacted. ${ }^{41}$ In its ultimate form, the amendment would liave added the word "independently" to the opening sentence of section 706 , so that the sentence would liave provided tliat the reviewing court sliall "independently decide all relevant questions of law." ${ }^{42}$ In addition, it would have added language to section 706 requiring courts to resolve issues of "agency jurisdiction or authority on the basis of the language of the

38. Id.

39. Id. at 23,499 (vote rejecting motion to table).

40. For detailed accounts of the legislative history, see, e.g., Ronald M. Levin, Judicial Review and the Bumpers Amendment, in 1979 ADMINISTRATIVE CONFERENCE OF THE U.S., RECOMMENDATIONS \& REPORTS 565, 566-70; Ronald M. Levin, Review of "Jurisdictional" Issues Under the Bumpers Amendment, 1983 DuKE L.J. 355, 358-66 [hereinafter Levin, Jurisdictional Issues]; James T. O'Reilly, Deference Makes a Difference: A Study of Impacts of the Bumpers Judicial Review Amendment, 49 U. CiN. L. REV. 739, 747-67 (1980).

41. S. 1080, 97th Cong., 2d Sess. $₹ 5$ (1982). This bill passed the Senate by a 94-0 vote, cleared a House committee, and died only because of strenuous efforts by the House Rules Committee during a lame duck session of Congress. See Prospects for Regulatory Reform Legislation, ADMN. L. NEws, Summer 1983, at 3.

42. 128 CONG. REC. 5,302 (1982). 
statute or, in the event of ambiguity, other evidence of ascertainable legislative intent." 43

To put it simply, the legislation would have encouraged courts to use their own judgment on issues of law in adininistrative cases, with little or no deference to what the agency might think. This certainly would have alleviated the tension between "craft" and "outcome" orientations: Congress would have totally eliminated the influence of "craft" norms of deference as a brake on a judge's pursuit of her favored "outcome" in the elaboration of regulatory law. For issues of "jurisdiction or authority," the amendment would have gone further and estabhished what was apparently intended as a sort of "reverse Chevron" principle: a clear statement rule under which an agency's interpretation of its jurisdiction would have had to be rejected in case of any ambiguity. ${ }^{44}$

The imphications of this episode seem clear: If one brought a proposal like Shapiro and Levy's to Congress, one would have to be prepared for that body to entertain amendinents that would conform with its own priorities and policy goals. The legislature is well equipped to craft compromises that can attract broad political support and capture the mood of the country; however, if one wants coherence and detachment from momentary political agendas, the legislature may not be the right place to look.

Perhaps this assessinent is too pessimistic. After all, Congress did manage in 1946 to pass section 706 without attaching ideological baggage, and many state legislatures have passed similarly apolitical scope of review legislation since then. Indeed, we may soon learn more about the legislature's capacity to enact coherent scope of review principles. Even as this is written, Congress is considering legislation on regulatory reform that would expressly adopt a standard of judicial review for agency interpretations of statutes im major rulenaking proceedings. ${ }^{45}$ No one can predict

43. Id.

44. That this was the intent of the "jurisdiction" provision is argued in Levin, Jurisdictional Issues, supra note 40 , at 358-70.

45. See S. 343, 104th Cong., 1st. Sess. (1995). Introduced by Senator Robert Dole, this bill would call upon a reviewing court to determine, inter alia, whether an agency's statutory interpretation "is clearly the interpretation of the statute intended by Congress" when judged by "traditional principles of statutory construction" and whether the agency "engaged in reasoned decisionmaking in determining that the [agency's] interpretation, rather than other permissible constructions of the statute, is the one that maximizes net benefits to society." Id. $\S \S 628(\mathrm{a}), 628(\mathrm{c})(1)(\mathrm{C})$. 
the upshot of this legislative struggle. But given the intensity of current debate inside and outside of Congress about the appropriate scope of regulation and of government itself, I would not bet on seeing a dramatic step towards "determinacy."

In the end, however, Congress's guidance may matter less than one would first expect. Shapiro and Levy's apparent assumption that "judges would not be in a position to ignore" the legislation they propose ${ }^{46}$ may underestimate the ingenuity of the courts. After all, section 706 currently states that "the reviewing court shall decide all relevant questions of law," but that language has not prevented the Chevron doctrine froin taking hold. On the whole, indeed, the influence of section 706 on the development of judicial review doctrine has been fairly meager. To Shapiro and Levy, the courts' capacity to ignore what Congress says about scope of review inay be disconcerting; perhaps we should be comforted instead.

\section{Shapiro ANd LeVy's Proposed Statute}

Despite my doubts about the wisdom of turning to Congress for repair of whatever weaknesses afflict modern scope of review doctrine, I welcome Shapiro and Levy's suggested statute as a contribution to the literature, because it furthers a necessary dialogue between commentators and the judiciary over the proper standards for judicial review of admimistrative action. Indeed, the authors graciously note that their suggested rewrite of section 706 is modeled in part on the "restatement of scope-of-review doctrine" adopted in 1986 by the American Bar Association's Section of Administrative Law, a project for which I was the draftsman. ${ }^{47}$ Accordingly, im this section, I will put aside my differences with Shapiro and Levy over the desirability of legislative action and examine their proposal as, in effect, a heuristic device that may cast light on the primciples that courts should observe, regardless of whether the principles ever appear in statutory form.

The format of a model statute is, in fact, a very good vehicle for exploring standards of review. It can induce drafters and readers to think about doctrine in a disciplined, concrete, and constrnctive way. For example, the tern of art "arbitrary and capricious"

46. See Shapiro \& Levy, supra note 1, at 1073.

47. See Levin, Restatement Report, supra note 12. 
by itself conveys almost nothing; ${ }^{48}$ the statutory format is conducive to an effort to state explicitly what specific errors would violate that criterion. Moreover, the format draws attention to the important problem of integrating prevailing standards of review into a coherent whole. Shapiro and Levy seem particularly interested in this last problem. ${ }^{49}$ They have made an articulate case for their proposal, but several cautionary observations seem worth making.

First, part of the authors' strategy in their statute ${ }^{50}$ is to restate existing law in a relatively "determinate" fashion so that courts cannot misunderstand their mandate. It is at least open to question, however, whether Shapiro and Levy have succeeded in offering language that would actually clarify the law. Thus, in subsection (C), the authors' use of epithets such as "specifically resolved," "unmistakable," and "unequivocally" might very well make the standard of review for issues of law narrower than current law, but I am by no means convinced that these terms would make the law less vague. Similarly, in their "abuse of discretion" subsections, Shapiro and Levy use unfamiliar phrases like "logically coherent explanation" and "valid policy explanation," which they themselves presumably understand, but which have no established caselaw gloss and might very well cause deep puzzlement for judges. In Universal Camera ${ }^{51}$ Justice Frankfurter anticipated 1983).

48. See William H. Allen, Chairman's Message, 35 ADMIN. L. REV. iii, vi (Spring

49. See Shapiro \& Levy, supra note 1 , at 1073.

50. The "key provisions" of the proposed statute, $i d$. at 1072, would direct courts to set aside an agency action if

(C) the agency decision violates its statutory mandate or other statutory provisions because:

(1) the issue has been specifically resolved by explicit statutory language;

(2) the issue has been specifically resolved by legislative history manifest-

ing an unmistakable congressional intent; or

(3) a contrary interpretation of the statute is unequivocally required by the traditional tools of statutory construction; or

(D) the agency has not offered a valid policy explanation for its decision because:

(1) it relied on policy concerns that were precluded by statute; or

(2) entirely failed to consider an important aspect of the problem; or

(E) the agency has not offered a logically coherent explanation in terms of agency expertise, credibility determinations, or policy considerations, of

(1) why the evidence in the record supports its decision; or

(2) why the contrary evidence does not preclude the decision.

51. Universal Camera Corp. v. NLRB, 340 U.S. 474 (1951). 
perfectly the difficulty faced by the authors: "Since the precise way in which courts interfere with agency findings cannot be imprisoned within any form of words, new formulas attempting to rephrase the old are not likely to be more helpful than the old. There are no tahismamic words that can avoid the process of judgment." ${ }^{.52}$ Nevertheless, to the extent that Shapiro and Levy's real objective is to dampen what they call "overly aggressive judicial review," do the job more effectively than current formulas do.

Second, the proposed statute seems less successful in terms of the authors' aspiration to curb what they call "manipulable categories to which different degrees of deference apply." they criticize current scope of review doctrine on the ground that courts can pursue personal agendas by alternatively choosing to decide a case under the deferential Chevron standard or the State Farm "hard look" standard. ${ }^{55}$ Therefore they intend to "clarify the relationship between Chevron and State Farm as part of a single inquiry." 56 Surprisingly, their statute leaves room for exactly the same maneuver. Apparently, a court could invalidate an agency action for "rely[ing] on policy concerns that were precluded by statute" under subsection (D)(1), even if the alleged misreading of the statute were not "explicit," "unmistakable," or "unequivocal" within the ineaning of subsection $(\mathrm{C}) .^{57}$

Of course, Shapiro and Levy could head off this tactic by making clear that subsection (D) reversals would have to meet the same rigorous standards as im subsection (C), but then they would need to explain why they have included two subsections in the first place. Part of the problem here is that the authors have too uncritically committed themselves to the four-factor formula of State Farm instead of recognizing that the Court's test in that case is framed in a confusing manner. One factor that can make a rule arbitrary, according to State Farm, is that "the agency has rehed on factors which Congress has not intended it to consider." 58 The

52. Id. at 489 .

53. Shapiro \& Levy, supra note 1 , at 1070.

54. Id. at 1062.

55. See id. at $1063-66 \&$ n.55.

56. Id. at 1073-74.

57. The same maneuver might be possible under subsection (D)(2), depending on how that provision is construed. See infra note 63.

58. Motor Vehicle Mfrs. Ass'n v. State Farm Mut. Auto. Ins. Co., 463 U.S. 29, 43 
Court should never have characterized this issue as part of abuse of discretion review. To do so "create[s] an overlap between arbitrariness review and the legal question of whether the agency acted beyond its legal authority-a question that the court logically should confront before reaching the issue of arbitrariness." 59

Third, the proposed statute revives the questions I broached earlier as to how much we should pursue "deterininacy" as opposed to other values. For example, the acceptability of subsection (C), Shapiro and Levy's version of step one of the Chevron test ${ }^{60}$ would seem to depend directly on one's attitude towards the substance of the Chevron standard. I will not discuss the merits of that issue here, because Shapiro and Levy theinselves do not address it. My point is simply that unless one is prepared to take a stand on the relative authority and competence of courts and agencies in the interpretation of statutes, one cannot meaningfully decide whether the manner in which Shapiro and Levy have struck the balance between agency autonomy and judicial control is attractive. The goal of "deterininacy" should not resolve the issue by itself. Similarly, subsection (C) would adopt a particular position on the relative weight of text, legislative intent, and "traditional tools of construction" in the interpretation of statutes; yet this is a position that demands a substantive analysis, not just an appeal to consistency for the sake of consistency. ${ }^{61}$

Fourth, in an attempt to simplify "abuse of discretion" review, Shapiro and Levy's proposed statute would go even further and would entirely wipe out several established and familiar inquiries that courts have commonly used in deciding whether an agency action is "arbitrary and capricious." Some of these inquiries may have been omitted simply because the authors failed to think about them. For example, their proposed statute appears to contain no language that would authorize a reviewing court to set

(1983).

59. ERnest Gellhorn \& Ronald M. LeVIN, ADMinistrative LAW and Process IN A NUTSHELl 98 (3d ed. 1990).

60. Chevron, U.S.A., Inc. v. Natural Resources Defense Council, 1nc., 467 U.S. 837, 842 (1984).

61. Even assuming that it is realistic for the authors to propose that Congress pass a statute purporting to settle the debate over the relative authority of text, legislative histo$\mathrm{ry}$, and canons in the construction of statutes, I have to wonder whether it would make sense for a legislature to codify a philosophy of statutory interpretation for administrative law cases alone, leaving uncodified the ground rules for resolving every other type of statutory dispute. 
aside an agency action that violates the agency's own regulations. The proposition that an agency is bound by its own rules (or at least its "legislative" rules) is both fundamental and uncontroversial, and it is difficult to believe that Shapiro and Levy would seek to abolish it. ${ }^{62}$ Similarly, the proposed statute cannot readily be construed to allow a court to strike down an action because the agency acted inconsistently with its own prior positions or precedents and failed to explain why. ${ }^{63}$ This omission is curious because State Farm itself largely turned on this principle. ${ }^{64}$

Other omissions, however, appear to be quite deliberate. For example, to judge from the most natural reading of subsection $(E)$, Shapiro and Levy propose to strip courts of their power to hold that an agency action is invalid because the agency lias drawn a factual conclusion that no reasonable person could have reaclied on the basis of the evidence in the record. In otler words, the court would apparently have to uphold the challenged action if the agency's explanation for its factual perceptions is "logically coherent" (a phrase tliat would seem to denote mere intelligibility),

62. A purist might argue that an agency that violates its own regulation has not "abused its discretion," but rather has taken an action with respect to which it had no discretion (just as if it had violated a statute). Indeed, the ABA restatement followed this analysis. See Levin, Restatement Report, supra note 12 , at 248 . On the other hand, the only language in the current APA that supports the doctrine is in the so-called abuse of discretion clause, 5 U.S.C. $\S 706(2)(A)$ (1988), which allows a court to set aside agency action that is "not in accordance with law." Whichever view one takes, Shapiro and Levy need to take account of the doctrine somewhere.

63. It is couceivable that Shapiro and Levy would regard the agency's past position as "an important aspect of the problem," which the agency must "consider" under their subsection (D)(2). Elsewhere, however, they seem to contemplate that the latter language would implicate only statutory issues. See Shapiro \& Levy, supra note 1, at 1073 (citing Levin, Restatement Report, supra note 12, at 250-53). They probably must endorse some such limitation. As the cited section of the restatement report explains, a standard of review that would permit judges to insist that agencies discuss every issue that they personally regard as "important," without regard to whether those issues are anchored in the statute, would authorize precisely the kind of open-ended, "outcome-oriented" review that Shapiro and Levy are trying to prevent. See also Pension Benefit Guaranty Corp. v. LTV Corp.; 496 U.S. 633, 646-47 (1990) (holding that an agency is not required to consider the policies embedded in statutes other than the one it is enforcing-from which it would seem to follow, a fortiori, that the agency is also not required to consider policies that are embedded in no statute at all).

64. See Motor Vehicle Mfrs. Ass'n v. State Farm Mut. Auto. Ins. Co., 463 U.S. 29, 51 (1983) ("We hold only that given the judgment made in 1977 that airbags are an effective and cost-beneficial lifesaving technology, the mandatory passive restraint rule may not be abandoned without any consideration whatsoever of an airbags-only requirement."); $i d$. at $41-42,57$ (explaining need for reasoned analysis when an agency changes its course). 
even if the court thinks those perceptions are dead wrong. It is hard to beheve that the authors would go so far as to abolish a variety of rationality review that (at least in its "substantial evidence" mode, which Shapiro and Levy intend to subsume within this subsection) has been part of judicial review of administrative action almost from its beginnings.

What would they do, for example, with a case like Bowen $v$. American Hospital Ass' $n$ ? ${ }^{65}$ In this case, the Secretary of Health and Human Services imposed measures designed to prevent hospitals from discriminating against handicapped newborn infants. In the Supreme Court, the government conceded that a hospital policy that makes treatment decisions based on parental wishes is not discriminatory, because it places the handicapped and nonhandicapped on the same footing. Even so, the government argued that "regardless of its 'inagnitude,' there [was] sufficient evidence of 'illegality' to justify 'establishing basic mechanisms to allow for effective enforcement of a clearly applicable statute. " "Th That was certainly a "logically coherent" explanation: what made it untenable and the regulation invalid, according to a plurality of the Supreme Court, was that the government could not point to a single instance in which a hospital had refused treatment in the absence of parental consent. ${ }^{67}$

At least as a inatter of logic, such an analysis does not require the reviewing court to take a stand on the "ultimate policy issue"; it only requires the court to consider the strength of the evidence. Shapiro and Levy may contend that to accord judges this prerogative poses too great a risk of judicial "outcome orientation," but perhaps removing this sort of check on agencies gives them too much power to take action without bothering to find out if their perceptions of the world conform to reality. ${ }^{68}$ The curtailment of judicial review of the strength of the evidence seems especially questionable as applied to agency adjudications. If an

65. 476 U.S. 610 (1986).

66. Id. at 633 (plurality opinion) (quoting $49 \mathrm{Fed}$. Reg. 1645 (1984)).

67. Id. at 633-36.

68. See International Union, UAW v. OSHA, 37 F.3d 665, 669 (D.C. Cir. 1994) ("The requirement of supportive evidence operates to assure a link between the agency's substantive nuandate and the real-world circumstances in which the agency operates. If an agency could claim to be applying a statutory constraint merely by asserting the existence of sone fact .... it would be free to defeat the underlying purpose of the constitutional himits on delegation ....."). 
agency imposes a sanction on an individual who claims to be totally imocent, most of us would think that a court ought to consider not only whether the agency has given a "coherent" explanation of its view of the evidence, but also whether the evidence would in fact reasonably support the charge. ${ }^{69}$

If I have taxed the reader's patience with too much detail in this Part, I did so to illustrate the difficulty of drafting scope of review standards that are both clear and compatible with the functions that we want judicial review to serve. Perhaps others could make similar points about the ABA restatement; I intend no adverse comparison here. Readers may examine both sets of standards and take their pick. This review of some of the potential problems in Shapiro and Levy's draft statute should serve, however, to underscore my earier comments about the limits of what we can expect from scope formulas (whether codified or otherwise). Given the inherent complexities of the subject matter, perhaps the Court is wise to avoid moving too quickly to attempt to settle the law.

\section{CONClusion: THE ROLE OF SCHOlARSHIP}

In this comment, I have accepted the thrust of Shapiro and Levy's descriptive claim: that the institutional characteristics of the courts tend to impede them from articulating and conforming to durable, consistent scope of review principles. Unlike the authors, however, I am skeptical about the extent to which one should deinand orderliness and analytical clarity of doctrine. At times courts have legitimate reasons for wanting to keep their options open, including their responsibility for maintaining the coherence of the substantive law.

Indeed, a body of judicial review doctrine that would tie judges' hands so tightly as to lead to determinacy of result might be neither achievable nor satisfying. Efforts to induce judges to

69. I may be mistaken in supposing that Shapiro and Levy mean to eliminate this sort of review. After all, they profess to be codifying the four-factor State Farm formula for abuse of discretion review, which did endorse judicial consideration of the strength of the evidence. See Motor Vehicle Mfrs. Ass'n v. State Farm Mut. Auto. Ins. Co., 463 U.S. 29,43 (1983) (stating that a rule is arbitrary if agency "offered an explanation for its decision that runs counter to the evidence before the agency"). But if they do contemplate retaining this element of judicial review, I fail to see how they can claim to be improving the clarity of section 706. 
approach broad classes of problems using a consistent method of analysis are generally likely to be more fruitful, but even that objective should be tempered by a recognition that the problenis in this area are elusive. My critiques of Shapiro and Levy's model statute are intended to einphasize how easily efforts to achieve predictability can drift towards oversimplification.

Notwithstanding these cautionary renarks, which were inspired by Shapiro and Levy's resolute enıphasis on achieving "determinacy," I certainly sympathize with their wish that judicial review doctrine should be clearer than it is. But how can clarification become a reality, given the institutional forces that constrain the courts as well as (at least in my estimation) the Congress?

Though it sounds pretentious, I suggest that an unusually large share of the burden has to fall on the scholarly community. Treatises and articles that attempt to describe and evaluate the overall patterns are a necessary corrective to the largely unavoidable inconsistencies of the judicial hiterature. Our credibility in these circumstances coines not froin our superior wisdoin, but simply froin our opportunity to think about these issues in ways that judges often cannot or will not when they are preoccupied with resolving a substantive question and assenbhing a majority in a single case. I sometimes compare scope of review doctrine to a mosaic design that can only be appreciated when observed fron several paces away. In similar fashion, scholarly distance, which is so often an impediment to understanding, can also facilitate insight in this particular setting.

Of course, the Supreme Court has final responsibility for the shape of federal law, and when it takes a firm stand, the coninientators, hike the lower courts, nuust take the Court's position seriously. But when we observe that the Court's actions speak more loudly than its words, we can at least report this fact and distinguish the situation from others in which the Court acts as though it neans what it says. And when formulas spoken in one context work out awkwardly in another, we can explain why that is so. Any effort to devise a rational division of labor between the judiciary and the acadeny should take account of these possibilities.

This claim of authority for scholarship will only nrake sense, however, if commentators are willing to read enough cases to give their generalizations credibility and to be appropriately skeptical when the judiciary's actual behavior does not seein to jibe with its declared intentions. Analyzing a few "leading" cases in a vacuun, 
as too many articles in this area do, is no substitute for looking to see what is actually going on in the caselaw as a whole.

For several reasons, it is not easy to do the sort of research that I am urging. The caselaw is almost hmitless-after all, virtually every administrative case that courts decide on the merits can be said to contain a scope of review issue. Standard key numbers do not necessarily retrieve all the relevant cases. Moreover, scope of review research demands that the investigator read opinions closely to see how the court actually arrived at its result-which may not be the saine as the kind of reasoning the court said it would apply in the portion of its opimon labeled "Standard of Review."

But this warning serves only to remind us of Justice Scalia's wry advice in the pages of this journal a few years ago: "Administrative law is not for sissies." 71 The proof that Shapiro and Levy are no sissies is that they have had the nerve to offer their model for judicial review in a public forum-particularly with critics like inyself on hand to raise questions about it. Now one hopes that others will follow their lead, recognizing both the difficulty of the material and the exceptional need for scholarly work in this challenging area.

70. These comments are not intended to dismiss out of hand the sort of computerassisted research into caselaw that Shapiro and Levy, among other scholars, have put to use. See Shapiro \& Levy, supra note 1, at $1065 \mathrm{nn} .62$, 64. See generally Peter H. Schuck \& E. Donald Elliott, Studying Administrative Law: A Methodology for, and Report on, New Empirical Research, 42 ADMIN. L. REV. 519 (1990) (exploring methodological issues). No doubt the utility of this technique varies with the precise question being investigated.

71. Antonin Scalia, Judicial Deference to Administrative Interpretations of Law, 1989 DUKE L.J. 511, 511. 